\title{
FROM EMBODIMENT EYE TO INCORPOREAL BODY
}

\begin{abstract}
Ali Şahan KURU ${ }^{1}$
ABSTRACT

In this article, I tried to examine the equivalences of different visual regimes, from the invention of perspective to digitally created images. Information control, society and power 21st Century. Orwell's Big Brother in the contemporary society entered our lives as a metaphor through surveillance cameras. We live our life conscious that we are being watched. Moreover, we are both watched and watching through Internet technologies. How does the knowledge of being watched impact our lives? The control of information and people through censorship is still created through governmental pressure on the media. So, could the Huxley's 'soma' met with mass media tools, which appear to acknowledge only through its pleasure content? How do mechanically reproduced visuals, which situate the world beyond the human eye level? on a different level from a point of human eye, impact ties with reality? I will strive to answer these questions.
\end{abstract}

Keywords: Cartesian perspective, Panopticon, Surveillance, Big Brother, Drones, Internet

Kuru, Ali Şahan. "From Embodiment Eye to Incorporeal Body". idil 6.32 (2017): 1241-1252.

Kuru, A.Ş. (2017). From Embodiment Eye to Incorporeal Body. idil, 6 (32), s.1241-1252.

\footnotetext{
${ }^{1}$ Doktora Öğrencisi, Mimar Sinan Güzel Sanatlar Üniversitesi, Sosyal Bilimler Enstitüsü, Batı Sanatı ve Çağdaş Sanat Programı, alisahankuru(at)gmail.com
} 


\section{BEDENSIZ GÖZDEN CisiMSiz BEDENE}

\section{öz}

Bu çalışmada perspektifin icadından, dijital imajlara kadar farklı görsel rejimler ve aralarındaki ilişkiler incelenmiştir. Orwell'in Büyük Abi'si modern toplumların gündelik yaşamına gözetleme kameralarıyla bir metafor olarak girdi. Hayatımızı gözetlendiğimizi bilerek yaşıyoruz, üstelik internet vb teknolojiler sayesinde hem gözetliyor hem de gözetleniyoruz. Gözetlendiğimiz bilinci hayatımıza ne şekilde etki ediyor? Bilginin ve toplumun kontrolü hala iktidarın medya üzerindeki sansür mekanizmaları ile sağlanıyor. Öyleyse Huxley'in Soma'sı sadece hazcı bir içeriği kabul eden kitle iletişim araçlarıyla birlikte düşünülebilir mi? İnsani ölçekte bir bakışın boyutlarını aşarak mekanik olarak yeniden üretilen görseller gerçeklikle olan bağlarımızı nasıl etkiliyor? Bu çalışma bu soruları tartışarak cevap vermeye çalışacaktır.

Anahtar Kelimeler: Kartezyen Perspektif, Panoptikon, Gözetleme, İnsansız Hava Arac1, İnternet 


\section{Introduction}

The final scene of the Michelangelo Antonini's movie Blow Up dated 1966 goes like this; While strolling in the park, the main character who is a photographer sees a group of pantomimes playing tennis at a tennis court with a make-believe ball. With convincing mannerisms, the players throw the make-believe ball to each other with make-believe rackets. They chase the ball where it falls and move their bodies precisely as they would in a real game. These scenes are shot silent except for the distant sounds of birds. This quietness is a metaphor for a life experience shaped by only one hearing sense with an aim of linking a living thing. The camera follows the ball together along with the pantomimes. Then something interesting occurs; the invisible ball falls out of the game court and lands by the photographer who has been watching the game with much interest. All the pantomime performers look at the photographer who runs to pick up the ball. He puts his camera down, picks up the make believe ball and pretends to throw it back to them. This scene is interesting because in his act of putting the camera down to be able to throw the ball, the photographer has drifted away from reality. It is further interesting because the photographer has been searching for a clues about a real murder that he photographed himself previously in the same park. In the photograph taken by the same photographer in the same park, the photographer discovers a dark spot among the bushes. This dark spot was not a result of a conscious selection of the photographer but a purely accidental stain. This stain provokes the photographer's curiosity. Suspecting a hidden reality within the spot, he repeatedly blows up the photograph in order to clarify the image. This dark spot resembles a gun that targeted a man in the park. The photographer recreates his own fiction of the photograph in a new context. The film asks one question: Are there two identical worlds; the world of physical reality seen by eyes and the world captured by a photographic camera. The camera reveals everything within a fixed a moment forever.

The eye is not capable of fixing the moment and materializing it. However, the eye enables us to construct a perception of the world in collaboration with other senses. The transformation of perceptions into information at a conscious level becomes possible together with the contexts in which experiences of the individual and the things experienced occur. How do we take a stand at the point of the two optical experiences that are shaped by the perception? In Blow Up, the photographer obsessively blows up the black spot in search of a trace of the murder even though the spot can be perceived as a gun or anything that might be associated with the murder only by looking at it from a distance. What the photographer believes it to be disappears when the spot is blown up. The machine has seen something but does not led the eye transform the narration into reality in this sense, because the reality has 
been stripped of its time and space, its context, the possible reality the machine sees cannot be materialized. Because it is not completely conceived, the photograph is being blown obsessively. But the more it is blown up the more it becomes meaningless. However, the photographer gives himself into the virtuality by throwing back the virtual ball together with the pantomimes. He believes in the invisible ball that he does not see more than the possible murder that he has seen. Because the virtual reality that the pantomimes produced in this sense is quite consistent in itself and perfectly produced, it is easy to grasp and to control. Nevertheless, the possible real murder in the real park shown in the photograph is deprived of such consistency. According to Aristotales, "as oppose to the historian who writes the realities as they are; a poet's narration of the realities is to recreate the reality rather than copying it" (1987: 30) While the history is limited to what happened, a poem's fiction has infinite choices of possibilities. We cannot say fake to what pantomimes create because they are creating their games by copying the real. Where the photographer and the pantomimes conjoined is linked to the understanding of Apollo and Dionysus is conflicted in terms of the practices of understanding and knowing the world of the two perceptions. Camille Paglia (1991: 110) explains the Apollon side as providing conscious, order, and form, whereas Dionysus is characterized as the subconscious. The pantomimes in the film steps into the scene as a screaming bunch on a fast moving vehicle. This entry can be read as a reaction of Dionysus of sensations to Apollo of conceptualization and cognition. The photographer is posed as inactive, who watches the game completely from outside. When he participated in their game he was situated between the fact and fiction. The act of his pretending of throwing the ball does not break the ties with the reality, with a possible connection to Jean Baudrillard, because it is not make-believe within the fiction that is produced within the reality as seen at the specific scene of the film. This can be tied to Baudrillard's Simulacra and Simulation (2003) theory in terms of fiction transforming into reality. Baudrillard mentions blurriness of the border between the reality and imaginary. "Whatever is made during a real event, the same things are made in an event of simulation; the same signs are used. They are not any different from real signs in terms of established orders." (Baudrillard, 2003: 44).

\section{Photographic Image as a Tool to Gain Information}

In search of the evidence about a murder, the photographer strives to reveal what is in the dark. The photographic image becomes a tool for searching, proving, and knowing, not a visual experience. The reproduced image, making meaning by framing itself, is a version of the power of the absolute eye that is defined by Michael Foucault; "The eye of surveillance, the eye of the government, the eye of the researcher is the eye which tries to reveal the reality hidden behind the social which makes the private public" (Denzin, 1995: 52). According to Denzin, all the ways of 
seeing, which are dependent on epistemology claim that realistic statements about the world can be made. The eye is independent of both seeing and being seen. This belief of independence of the eye makes it possible to build a disinction between the seeing and knowing. Therefore, the independent and powerful eye presents pure information and gaze exempt from such factors as gender, race, status, and ethnicity, which create a social separation. In this Cartesian manner of thought, the information gained from the gaze remains pure, reaching knowledge about the world through removing other contexts by which the meanings are made.

The photographic camera was invented in 1839. At that time, August Comte was completing his work, Notes on Positive Philosophy. Thus, Positivism grew concurrently with the growth of photographic devices and sociology. The scientists aimed for the applicative sustainability of both and believed that they were going to offer holistic information about human beings, nature, and society. Rationalism was going to replace metaphysics; planning was going to end societal conflicts, and reality was going to replace subjectivity. "Any darkness and hidden in the soul was going to be enlightened with the empirical information" (Berger, 1998: 94). The swap of reality with subjectivity means clearing the threat of the world - creating a space controlled by an embodiment eye. The separation of the seer and person being seen, and the individual and the object which started with 17 th century positivism, paved way to the restructuring of the world. In his article, Scopic Regime of Modernity, Martin Jay (1998) connects the perspective that occurred as a result of the effort of reaching the real vision in Cartesian thought to the Renaissance painting. Jay, describes the supreme domination of the sense of sight over other senses and so asserts that the cartesian perspective is the most dominant sight regime of the modern world. Cartesian perspectivalism is a way of seeing both then and now, a method of perception that represents space and the subjects and objects in that space according to the rules of Euclidean geometry. "Natural experience of sight valorized by the scientific world view" (Jay, 1998:6) he noted. He also explains how the two Renaissance artists, Alberti and Brunelleschi, developed perspective and aligned it with Descartes's philosophy. According to the Cartesian model, mind is equivalent to eye. (What we see is real). "In the Cartesian model the intellect inspects entities modeled on retinal images" (Jay, 1998: 7). In this way sight is considered to be static and monocular while space becomes abstract and unified. Therefore, cartesian perspective creates disembodied sight. One, who is looking through the peephole places himself/herself out of the scene and tries to capture an eternal moment. This situation constitutes "a harmony between the mathematical regularities in optics and God's will." (Jay, 1988: 6) Controlling the world through sight without any interaction is an important metaphor for some modern governmental forms. The eye of the God, transformed as panopticon, enters daily life as a signifier of the inspection of the 
government over the society. In the late 18th century, English social theorist Jeremy Bentham, developed an architectural plan for an ideal prison that he called the Panopticon. This prison would consist of a circle of individual cells surrounding an observation tower. Each of the cells would open toward the tower and be brightened by its own outside window. A single guard in the observation tower could keep watch on many prisoners each of whom would be individually secured and locked down without himself as a gazer being seen. This leads the prisoners who do not see their supervisors, to believe that they are being watched at all times, even if sometimes they are not. This inspection is not a governmental tool necessary to sustain its own continuity of the totalitarian regime. Panopticism was a method that had the potential of orientation of the 'observed' through creating a categorical separation between the seer and seen and by naming, categorizing, and producing some out of context transparent information. Bentham's initial concept was later invoked by Michel Foucault in Discipline and Punish: The Birth of the Prison as a metaphor for modern disciplinary societies and their pervasive inclination to observe and normalize. Foucault proposed that not only prisons, but all hierarchical structures - armies, schools, hospitals, and factories have evolved through history to resemble Bentham's Panopticon. Further, as quoted in David Lyon (1998), The Electronic Eye: The Rise of Surveillance Society, Foucault says "Bentham made visibility a trap" to induce in the inmate a state of conscious and permanent visibility that assures the automatic functioning of power. This arrangement is such that surveillance is permanent in its effects, even if it is discontinuous in its action; that the perfection of power should tend to render its actual exercise unnecessary. "That this architectural apparatus should be a machine for creating and sustaining a power relationship independent of the person who exercises it; in short, that the inmates should be caught up in a power of which they themselves are the bearers" (Lyon, 1998: 57-80). The creation of the feeling of being seen led to the creation of a self-control mechanism through internalization of that power. No longer visible, the power of the invisible eye will shape the lives of modern society. Louis Althusser, even though he basically agrees with Foucault, argues that the power uses a variety of tools in order to make itself visible. (Althusser, 2008) These tools are elements such as varied social institutions, parties, clubs, and media such as radio, television, and printed materials. According to Althusser, the essential function of these tools is to make the power visible. 'Big Brother' stands precisely at the conjunction of the Foucault and Althusser's panopticism.

In his utopian country, Ocenia, George Orwell made power visible in Big Brother, which inspected every behavior of the people in order to establish a permanent hegemony of the governmental power over the society. In the novel, the ones who did not obey were isolated as 'the others'. The others who were punished by the government in a variety of ways were searching for ways to escape from the 
absolute eye of the power. In this context, the visibility of Big Brother was causing the creation of misinformation that was permeated and legitimized by the power. The dystopic narration of Orwell intimates the panopticon gaze concept revealed in the crime and punishment of Bentham. However, Foucault had interpreted Bentham's design, as an internalized method, a way to provide a person's own introspection instead of an external intervention. Many inspection tools that can be connected to Orwell's utopia are already part of our daily life. We are being observed 24 hours a day with hidden circuit systems, communication webs like the internet, surveillance cameras, and drones. There is only one difference. Instead of reacting against this inspection, the contemporary population thinks that this is done only for security purposes and that it is a practice necessary for maintaining the smooth flow of social life. Deleuze says that Foucault places the Orwellian style disciplinary societies in the 18th and 19th centuries (Deleuze 1997: 3-7). Disciplinary societies after the 1945's were replaced with 'inspection societies'. Government in inspection societies codes the individual as the self-inspecting eye without the use of vulgar force. Everybody inspects each other and maintains the validity of the information that is institutionalized by the inspecting power over the inspected. This is a method that it uses to stabilize its own inspection mechanism on a smallest scale in connection to the continuous exchange of inspecting and inspected. Deleuze compares discipline societies, which cover and engulf to 'mussels' and inspection societies to 'snakes' (Deleuze, 1997: 3-7). The eye in the inspection society is not an organ for interacting emotionally with the world, but a hunter that is used to destroy the effects that can be developed against its existence.

\section{War as an App for Smart Phones}

Internalized control enables the individual to maintain its existence by his/her compliance with the social order and norms. Foucault says that the modern society functions not through coercion but through cooperation (Sturken, Cartridge, 2005: 96). In his book titled “Amusing Ourselves to Death", Neil Postman (1985) explains why the power relations in modern societies do not need an Orwellian style discipline anymore. To Postman, knowledge production in the modern age switched completely from the written and verbal forms to the visual form. The visual gaze is not a cognitive gaze that produces meanings through categorizing the things that are experienced through the senses. The gaze of the modern person is more of a raw and pornographic gaze. No meaningful relationship between the seen object and seeing subject can be built, instead, the utility of the seen is emphasized. In other words, the image carries the value of momentary pleasure upon being deprived of time and space, instead of being a reflection of common concepts in public memory. The vision becomes ideological towards the intentions of its maker. Where the real world is 
transformed into simple images, simple images become real entities and effective motivations for hypnotic behavior. While the sense of touch was once the primary sense used in knowing, vision is now the most exclusive human sense. Seeing, which is most abstract and highly susceptible to deception, corresponds to the generalized abstraction of today's society (Debord, 2012: 40). Neil Postman starts his book like this:

\begin{abstract}
What Orwell feared were those who would ban books. What Huxley feared was that there would be no reason to ban a book, for there would be no one who wanted to read one. Orwell feared those who would deprive us of information. Huxley feared those who would give us so much that we would be reduced to passivity and egoism. Orwell feared that the truth would be concealed from us. Huxley feared the truth would be drowned in a sea of irrelevance. Orwell feared we would become a captive culture. Huxley feared we would become a trivial culture, preoccupied with some equivalent of the feelies, the orgy porgy, and the centrifugal bumble puppy. As Huxley remarked in Brave New World Revisited, the civil libertarians and rationalists who are ever on the alert to oppose tyranny "failed to take into account man's almost infinite appetite for distractions". In 1984, Huxley added, people are controlled by inflicting pain. In Brave New World, they are controlled by inflicting pleasure. In short, Orwell feared that what we hate will ruin us. Huxley feared that what we love will ruin us. (Postman, 2005: 13)
\end{abstract}

In Brave New World Huxley has two methods for controlling the masses. One of them was a drug that he called Soma. This drug was provided by the government and had different impacts determined by the dosage. But in essence, it was a biocontrol method that was designed to give pleasure to people who would eventually further withdraw into themselves. Another method was a method of learning during sleep, Hypnopedia, that was used for propaganda purposes. To assert that these methods, even though transformed over the years, are currently used by the government is perhaps a vulgar conclusion; however, the similarity between the pleasure provided by soma in Huxley's inspection society and the pleasure taken solely from the visual and its outcomes in the modern age is thought-provoking. As Baudrillard pointed out, the masses want the pretence? show? instead of meaning, and worship all the contents so long as some visual enticement is included (Baudrillard, 2009: 409-415). However, framing the visual as solely pleasure taken from the act of seeing as today's society's dominant character would not be enough in understanding the importance of the visual in our daily life anymore. Neil Postman was basing his criticism on the television viewing habit of the American society, being passive viewers subjected to visuals that are created for certain purposes and manipulated visuals. Television was an image regime that weakens the rational and critical ties with the flowing outer world. Nevertheless, the sources of the visuals manipulated by the television were real. It was not far from the traditional representation approach from which positivism was driven. The visuals were restructuring their own meanings through new contents that were attributed by the presenters. War scenes were not 
allowing any reflexive rejection or a bodily reflection against the realities the war. It was bloodless and painless. However, the image of a seagull covered in petroleum could express the core of the war and could replace, in our imagination, the pain created by the war. The vision was in the secure space of the imagery. The bird had really been smudged into the petroleum; however, we needed the television to find out what caused the bird's detriment; and so this is where the propagative impact of the image steps in. The bird was the allegoric narration of the flowing life, whereas the petroleum in which it was soiled was an allegory of why the life does not continue in normal conditions anymore. War was an allegoric thing for the viewer. We could see, but we were deaf to what we see. Our ties were broken with the reality of listening, feeling, and reacting the war. Because we were so indulged in the visual, we were ethically locked and neutralized (Robins, 1999: 116). Nevertheless, the image was still able to create an emotional shock because the source of the shock was our psychic ties with the reality not with the rational. Soma's impact in Huxley was realized for the numbed viewers in front of the TV, but it did not mean the removal of this impact. The screen replaces the reality, says Berger. "This exchange has double function because it arises from the encounter of the conscious with the real events. Rejecting the reality is not only rejecting the objectivity, it is rejecting a basic part of the subjective one" (Berger, 1985: 260). In many of articles and books written to express how injured our ties with the reality thanks to images, war and death watched in screen is excessively emphasized. The gap between the cruelty of war and reliability of image is a gap of depravity of the knowledge gained by seeing which is more rational between the knowledge gained by experiences. If we go back to the beginning of the essay, the main character of the Blow-Up was trying to make meaning out of murder and horror of the idea of death in connection to the gun he thought he saw. He had tried to blow up the photograph in an obsessive manner in order to get rid of the feeling of disturbance and fear that he had created in his mind. As quoted in Kevin Robin's book Into the Image, "a human being thinks that he/she can get rid of the fear if there nothing unknown left said Horkheimer and Adorno. For them, everything outside is a source of fear" (Robins 1999: 33). Blowing up in this sense is like jailing the empty space in which presence of the mind that sees the unknown up to its atoms. Presence is a possibility and possibility contains threat. After Einstein's relativity theory, artists had attempted to search for the 4th dimension. Picasso had tried catching the sequence of the time by activating the Cartesian eye that is observed from one point during the period of his analytical cubism. Together with the discovery of the atom our reality interaction that we built with the image had changed. Nowadays, the discovery of the byte, which is a building block of the digital technology, has once more transformed our relation with the reality and the representation. The images that surround us are not representations of the entities that are made up of atoms but digital codes that are made up of pixels. This is an alternative incorporeal nature reality. It is 
a reality that you cannot touch and cannot be touched by. This desire of controlling, at the same time, is a desire to escape from the defects and disorders of the physical things (Robins 1999: 37). We do not need to see anything anymore because there are digital machines that could see for us. Our cell phones continuously provide the whereabouts under record. Our computers are storing all our operations by turning them into lice. The new camouflages of the American soldiers are made up of pixel squares. Drones can make panoptic controls from a few kilometers of height. If a few pixels within the images sent by drones are not supposed to be there, they can be likely to be bombed. When the pixels are discovered to be smugglers, the photographs taken from the human distance were pressured not be included in the papers. Visual Technologies were visualizing the world by going over the distance out of our reach of conception and definition. Therefore, the world out of our sight did not sustain any sign about our existence.

In October 2012 James Bridle built a webpage named Dronestagram, similar to Instagram, allowed an instant ability to share photographs on the Internet. In this application that can also be downloaded on cell phones, Bridle was publishing photographs, via Google Earth, of the places at which CIA operations take place. He was sending the photographs together with information about the number of death toll and the casualties in places where the operations take place based on the CIA data. Even though taken right after the bombing, these photos were not as close as for us to discern any image of deaths or ruins. This way, the fearsome power of the war and killing was becoming an abstract map and people's lives as statistical information were sent and then erased on the cell phone screens. John Berger once wrote, "There is no body, no pain, no obligation - because obligation is a condition for existence too. These were rendering bodies of the reality. There is no longer need for a life experience" (Berger, 1985).

\section{Conclusion}

When Baudrillard mentioned the hyperrealism, he talked about how signs replaced the real things, and how operative twins are used in place of every kind of real process. This operative twin was taking its source from its similarity to the real one. We define our age as cybernetic utopia. The knowledge about the world is not constructed through our senses anymore. Moreover, even our eyes, which we were trusted the most since the cartesian perspective until the atom, do not know what they need to learn from what they see anymore. The faces that we are going to look on the screen belong to cyber identities. We stay far from the contact, and so, we poke to show our interest and we sink our cyber hand into the cyber body. Huxley's utopia has been crossed over and we are no longer numbs who build one-sided relations with the images that would shape us in front of the television; however, Orwell's Big Brother 
is over us in a further devilish form. Big Brother brought about a level where there is no longer discrepancy between subject and public by making transparent of the governmental pressure.

\section{KAYNAKLAR}

Aristoteles. Poetika. Çev. İsmail Tunalı. İstanbul: Remzi Kitabevi, 1987

Althusser, L. İdeoloji ve Devletin İdeolojik Aygitları. Çev. Alp Tümertekin. İstanbul: İthaki, 2008

Baudrillard, J. Simülakrlar ve Simülasyon. Çev. Oğuz Adanır. Ankara: Dogu Batı Yayınları, 2003

—. "The Precession of Simulacra". Cultural Theory and Popular Culture: A Reader. Harlow: Pearson, 2009

Berger, J. The Screen and the Spike. Londra: Chatto, Windus, 1985 1998

—. O Ana Adanmış. Çev. Müge Gürsoy Sökmen. İstanbul: Metis Yayınları,

Debord, G. Gösteri Toplumu. Çev. Ayşen Ekmekçi, Oktay Taşkent, İstanbul: Ayrıntı Yayınları, 2012

Deleuze, G. "Societies of Control”. October 59 (1992): 3-7

Denzin, K.N. The Cinematic Society: Voyeur's Gaze. London: Sage, 1995

Jay, M. "Scopic Regimes of Modernity". Vision and Visuality. (1998) Bay Press, 3-23

Lyon, D. The Electronic Eye: The Rise of Surveillance Society. Minneapolis: University of Minnesota Press, 1994

Paglia, Camille. Sexual Personae. New York: Vintage, 1991

Postman, Neil. Amusing Ourselves to Death, New York: Penguin Books, 2005

Robins, K. Imaj, Görmenin Kültür ve Politikası, Çev. Nurçay Türkoğlu. İstanbul: Ayrıntı Yayınları, 1999 
Sturken, M. Cartwright, L. Practices of Looking, Oxford University Press: New York, 2005 